\title{
DESAIN DIDAKTIS KEMAMPUAN PEMAHAMAN MATEMATIS MATERI BALOK DAN KUBUS SISWA KELAS IV SD
}

\author{
Epon Nur'aeni L \\ Muhammad Rijal Wahid Muharram \\ Universitas Pendidikan Indonesia Kampus Tasikmalaya \\ Jl. Dadaha No. 18, Tasikmalaya \\ Email: eponalamsyah@yahoo.com
}

\begin{abstract}
Didactic design of mathematic understanding competency of block and cube in fourthgrade elementary school student. Purpose of the research was to describe: (1) learning obstacles of mathematic understanding competency, (2) design of didactic learning material based on development of a block and cube material understanding competency, (3) implementation of the design of didactic learning material based on development of a block and cube material understanding competency. The research used didactic design research and analyzed qualitatively. An instrument was writing test. Research procedure: prospective analysis, experiment and restropective analysis. Results of the research were an alternative didactic design which could be used in elementary school mathematic learning.
\end{abstract}

Keyword: didactic design, mathematic understanding, block and cube concept, elementary

\begin{abstract}
Abstrak: Desain Didaktis Kemampuan Pemahaman Matematis Materi Balok dan Kubus Siswa Kelas Iv Sekolah Dasar. Penelitian ini bertujuan mendeskripsikan: (1) learning obstacle kemampuan pemahaman matematis,(2) desain didaktis bahan ajar berbasis pengembangan kemampuan pemahaman matematis materi balok dan kubus,(3) implementasi desain didaktis bahan ajar berbasis pengembangan kemampuan pemahaman matematis siswa materi balok dan kubus. Subjek siswa kelas IV SD dengan lokasi penelitian di SDN 1 Pengadilan. Penelitian ini menggunakan penelitian desain didaktis dan dianalisis kualitatif. Instrumen berupa tes tertulis. Prosedur penelitian: prospective analysis, eksperiment dan retrospective analysis. Hasil penelitian ini adalah suatu desain didaktis alternatif yang dapat digunakan dalam pembelajaran matematika SD.
\end{abstract}

Kata kunci: desain didaktis, pemahaman matematis, konsep balok dan kubus, SD.

Pembelajaran geometri pada konsep balok dan kubus sangat penting dipelajari untuk siswa SD. Konsep ini, sering ditemui dalam kehidupan sehari-hari, misalnya pada bentuk benda-benda di lingkungan sekitar. Hal tersebut sejalan dengan NCTM (2000) yang menjelaskan bahwa terdapat lima standar isi dalam pembelajaran matematika yang salah satunya adalah geometri (geometry). Geometri memiliki peluang lebih besar untuk dipahami siswa dibandingkan cabang matematika yang lain karena ide-ide geometri seperti titik, garis, bidang, dan ruang sudah dikenal oleh siswa sejak sebelum mereka masuk sekolah.

Meskipun geometri sudah dipelajari di sekolah, hasil-hasil penelitian menunjukan bahwa geometri kurang dikuasai oleh sebagian besar siswa. Hal tersebut didukung oleh studi pendahuluan yang dilakukan peneliti di SDN I Pengadilan. Hasil studi 
pendahuluan menunjukkan bahwa banyak siswa tidak dapat menjawab dengan benar ketika diberikan soal. Siswa masih belum memahami konsep bangun ruang. Siswa belum memahami konsep balok dan kubus. Siswa juga belum bisa mengelompokkan beberapa gambar yang termasuk balok. Siswa belum memahami unsur-unsur pada balok dan kubus. Siswa juga belum mampu mengungkapkan secara tertulis perbedaan balok dan kubus. Dari beberapa respon yang ada, terlihat bahwa siswa belum bisa menggambarkan balok dan kubus. Selain itu, siswa juga masih kesulitan untuk menghubungkan titiktitik yang dihubungkan menjadi bangun datar.

Menurut Purwanto (dalam Happisari, 2013) yang dimaksud pemahaman (comprehension) adalah tingkat kemampuan yang mengharapkan testee mampu memahami arti atau konsep, situasi, serta fakta yang diketahuinya. Dalam hal ini testee tidak hanya hafal secara verbalistis, tetapi memahami konsep dari masalah atau fakta yang ditanyakan. Sejalan dengan hal tersebut, Driver (dalam Ningsih, 2010) menyatakan bahwa pemahaman adalah kemampuan untuk menjelaskan suatu situasi atau suatu tindakan.

Dari pengertian tersebut ada tiga aspek pemahaman yaitu mengenal, menjelaskan, dan menginterpretasi/menarik kesimpulan. Selain itu, Winkel (dalam Happisari, 2013) menyatakan bahwa, pemahaman adalah kemampuan untuk menangkap makna dan arti dari bahan yang dipelajari. Adanya kemampuan ini dinyatakan dalam menguraikan isi pokok dari suatu bacaan, mengubah data yang disajikan dalam bentuk tertentu ke bentuk lain seperti rumus matematika ke bentuk kata-kata, membuat perkiraan tentang kecenderungan atau yang nampak dalam data tertentu seperti dalam grafik.

Dari beberapa pendapat di atas, dapat diketahui bahwa pemahaman adalah kemampuan untuk memahami suatu konsep, situasi dan fakta, sehingga konsep, situasi dan fakta tersebut dapat dijelaskan dan diinterpretasikan dengan bahasa sendiri. Pemahaman siswa terhadap konsep matematika menurut NCTM (dalam Kesumawati, 2008) dapat dilihat dari kemampuan siswa dalam: (1) mendefinisikan konsep secara verbal dan tulisan, (2) membuat contoh dan non contoh, (3) mempresentasikan suatu konsep dengan model, diagram dan simbol, (4) mengubah suatu bentuk representasi ke bentuk yang lain, (5) Mengenal berbagai makna dan interpretasi konsep, (6) mengidentifikasi sifat-sifat atau konsep dan mengenal syarat-syarat yang menentukan suatu konsep, dan (7) membandingkan dan membedakan konsep-konsep.

Pemahaman matematika dapat dipandang sebagai proses dan tujuan dari suatu pembelajaran matematika. Pemahaman matematik sebagai proses, berarti pemahaman matematik adalah suatu proses pengamatan kognisi yang tidak langsung dalam menyerap pengertian dari konsep atau teori yang dipahami pada keadaan dan situasi-situasi yang lainnya. Sedangkan sebagai tujuan, pemahaman matematik berarti suatu kemampuan memahami konsep, membedakan sejumlah konsep-konsep yang saling terpisah, serta kemampuan melakukan perhitungan secara bermakna pada situasi atau permasalahan-permasalahan yang lebih luas.

Selanjutnya Munir (dalam Ningsih, 2010) mengemukakan bahwa pemahaman matematika akan mampu menjelaskan atau membedakan sesuatu, kemampuan itu menyangkut: (1) penerjemahan (interpreting), yaitu verbalisasi atau sebaliknya, (2) memberikan contoh (exemplifying), yaitu menemukan contoh-contoh yang spesifik, (3) mengklasifikasikan (classifying), yaitu membedakan sesuatu berdasarkan kategorinya, (4) meringkas (summarizing), yaitu membuat ringkasan secara umum, (5) berpendapat (inferring), yaitu memberikan gambaran tentang kesimpulan yang logis, (6) membandingkan (comparing), yaitu mendeteksi hubungan antara 2 ide atau objek, (7) menjelaskan (explaining), yaitu mengkonstruksi model sebab-akibat.

Berdasarkan uraian tersebut, dapat disimpulkan bahwa kemampuan pemahaman matematika siswa menunjukkan kemampuan memahami materi pembelajaran, dari pemahaman ini akan mampu menjelaskan atau membedakan sesuatu. Berdasarkan berbagai pendapat dan paparan di atas dapat disimpulkan bahwa kemampuan pemahaman matematis adalah berupa salah satu tujuan penting dalam pembelajaran matematika yang dalam pelaksanaannya bukan hanya sebagai hafalan materi saja, namun lebih kepada pemahaman siswa terhadap konsep materi pembelajaran matematika itu sendiri.

Adapun beberapa hasil penelitian yang mengatakan bahwa, kesulitan yangdialami siswa yang memperoleh nilai rendah terletak pada kesulitan dalam memahami makna dari kata-kata dalam soal, kesulitan dalam mengubah kata-kata dalam soal ke dalam simbol, kesulitan dalam menentukan konsepkonsep yang tepat untuk digunakan, dan kesulitan 
menggunakan/menerapkan konsep-konsep dalam perhitungan matematis (Huda \& Kencana, 2013; Ariyanto, 2015; Purwatiningsih, 2013).

\section{Penelitian Desain Didaktis (Didactical Design Research)}

Sebelum proses pembelajaran berlangsung, seorang guru biasanya membuat perancanganan (desain) pembelajaran agar urutan aktivitas situasi didaktis dapat diupayakan terjadi. Desain didaktis dirancang guna mengurangi munculnya hambatan belajar (learning obstacle). Menurut Suryadi (2013, 12), penelitian desain didaktis (didactical design research) terdiri atas tiga tahapan, yaitu : (1) analisis situasi didaktis sebelum pembelajaran (prospective analysis) yang wujudnya berupa Desain Didaktis Hipotesis termasuk ADP, (2) analisis Metapedadidaktik, dan (3) analisis restrosfektif (restrospective analysis) yakni analisis yang mengaitkan hasil analisis situasi didaktis hipotesis dengan hasil analisis Metapedadidaktik. Dari ketiga tahapan ini akan diperoleh desain didaktis empirik yang tidak tertutup kemungkinan untuk disempurnakan melalui tiga tahapan DDR tersebut.

Dalam proses pembelajaran terdapat hubungan didaktis yang terjadi antara guru, siswa dan materi pembelajaran. Hubungan Guru-Siswa-Materi tersebut digambarkan oleh Kansanen (dalam Suryadi, 2013: 5) sebagai sebuah Segitiga didaktik yang menggambarkan hubungan didaktis (HD) antara siswa dan materi, serta hubungan pedagogis (HP) antara guru dan siswa dan hubungan antisipatif guru-materi yang selanjutnya bisa disebut sebagai Antisipasi Didaktis dan Pedagogis (ADP) sebagaimana diilustrasikan pada gambar segitiga didaktis Kansanen yang dimodifikasi berikut ini.

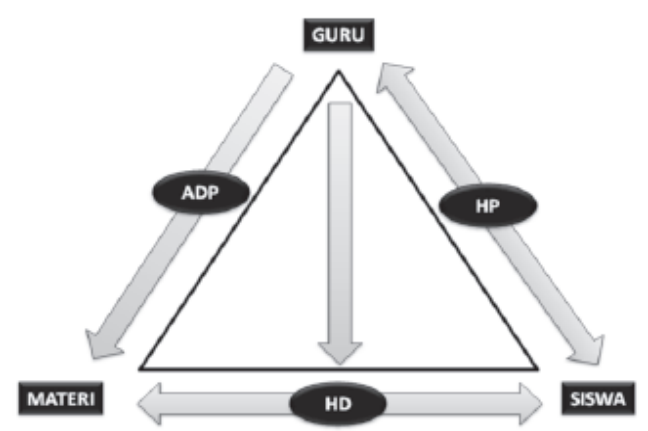

Gambar 1. Segitiga Didaktis yang Dimodifikasi
Pada gambar tersebut, terlihat bahwa peran seorang guru merupakan yang paling utama. Selain perlu menguasai materi ajar, guru juga perlu mengetahui hal lain yang terkait dengan siswa serta mampu menciptakan situasi pembelajan yang ideal bagi siswa. Dengan kata lain, guru harus mampu mengkolaborasikan ketiga komponen tersebut untuk menciptakan situasi pembelajaran secara utuh dan sesuai dengan siswa.

Menurut Brousseau (1997) "untuk menciptakan situasi didaktis maupun pedagogis yang sesuai, dalam menyusun rencana pembelajaran guru perlu memandang situasi pembelajaran secara utuh sebagai suatu obyek". Dengan demikian, guru harus mampu memprediksi berbagai kemungkinan respon siswa baik yang memerlukan tindakan didaktis maupun pedagogis yang perlu diantisipasi. Kemampuan guru yang telah dijelaskan di atas disebut sebagai metapedadidaktik. Sejalan dengan hal itu, Suryadi (2013:9) menyatakan bahwa metapedadidaktik adalah kemampuan guru untuk (1) memandang komponen-komponen segitiga didaktis yang dimodifikasi yaitu ADP, HD, dan HP sebagai suatu kesatuan yang utuh, (2) mengembangkan tindakan sehingga tercipta situasi didaktis dan pedagogis yang sesuai kebutuhan siswa, (3) mengidentifikasi serta menganalisis respon siswa sebagai akibat tindakan didaktis maupun pedagogis yang dilakukan, (4) melakukan tindakan didaktis dan pedagogis lanjutan berdasarkan hasil analisis respon siswa menuju pencapaian target pembelajaran.

Menurut Suryadi (2013) metapedadidaktik meliputi tiga komponen yang terintegrasi yaitu kesatuan, fleksibilitas, dan koherensi. Komponen kesatuan berkenaan dengan kemampuan guru untuk memandang sisi-sisi segitiga didaktis yang dimodifikasi sebagai sesuatu yang utuh dan saling berkaitan erat. Komponen fleksibilitas merupakan sebuah rencana terhadap prediksi renspon siswa, serta antisipasinya yang dipikirkan sebelum peristiwa pembelajaran berlangsung. Komponen ketiga adalah koherensi yaitu situasi didaktis yang diciptakan guru sejak awal pembelajaran, situasi didaktis ini tidaklah bersifat statis karena pada saat pembelajaran respon siswa yang muncul berbedabeda yang dilanjutkan dengan tindakan didaktis atau pedagogis yang diperlukan. Dengan demikian, metapedadidaktik merupakan strategi yang dimiliki guru untuk memperoleh solusi dan pengalaman pengajaran dalam berbagai situasi pembelajaran 
yang menantang dan tak terprediksikan, sehingga dapat dijadikan bahan refleksi dan evaluasi untuk perbaikan kualitas pembelajaran selanjutnya.

\section{Teori-Teori Pembelajaran yang Relevan}

Freudenthal (Hadi, 2005) berkeyakinan bahwa siswa tidak boleh dipandang sebagai passive receivers of ready-made mathematics (penerima pasif yang sudah jadi). Jadi, siswa harus terlibat secara aktif dalam proses pembelajaran. Siswa harus diberikan kesempatan untuk menemukan kembali matematika dengan cara mereka sendiri. Selanjutnya Hadi (2005.37) mengemukakan bahwa di dalam PMR, pembelajaran harus dimulai dari sesuatu yang riil sehingga siswa dapat terlibat dalam proses pembelajaran secara bermakna.

Di sisi lain, Bruner (dalam Suwangsih dan Tiurlina, 2010:86) menganggap bahwa berusaha sendiri untuk mencari pemecahan masalah serta pengetahuan yang menyertainya, menghasilkan pembelajaran yang bermakna. Bruner juga mengungkapkan bahwa siswa harus berpartisipasi aktif untuk memperoleh pengalaman dan melakukan eksprerimen-eksperimen yang membuat siswa menemukan suatu konsep. Belajar penemuan akan meningkatkan rasa ingin tahu siswa dan memberikan motivasi untuk terus belajar sampai siswa menemukan penyelesaiannya. Adapun kelebihan pengetahuan yang diperoleh siswa melalu belajar penemuan diantaranya akan bertahan lama dalam ingatan siswa, memudahkan siswa dalam penerapannya, dan meningkatkan penalaran siswa serta melatih kognitif siswa untuk memcahkan masalah tanpa bantuan orang lain. Bruner (dalam Suwangsih dan Tiurlina, 2010) mengemukakan bahwa dalam proses belajar, siswa melewati tiga tahapan yaitu: enaktif, ikonik dan simbolis.

Di sisi lain, Van Hiele (Crowley dalam Nur'aeni, 2010) menyatakan bahwa terdapat lima tahap belajar anak dalam belajar geometri, yaitu tahap pengenalan, analisis, pengurutan, deduksi, dan akurasi. Desain didaktis kemampuan pemahaman matematis siswa pada materi balok dan kubus yang dibuat ini, diharapkan dapat memberikan makna terhadap pembelajaran balok dan kubus itu sendiri yang berawal dari kehidupan seharihari dan memperhatikan karakteristik learning obstacle siswa yang muncul, kemudian membuat pembelajaran yang bermakna untuk siswa dengan menggunakan media pembelajaran yang langsung mengajak siswa untuk berperan aktif. Desain didaktis bahan ajar koneksi matematika ini akan meminimalisir learning obstacle yang muncul dan menambah pemahaman siswa terkait materi balok dan kubus.

Berdasarkan hasil studi pendahuluan yang peneliti lakukan ternyata siswa mempunyai hambatan belajar (learning obstacle) pada materi bangun ruang khususnya balok dan kubus. Padahal materi tersebut telah dijelaskan pada pembelajaran sebelumnya di kelas IV semester 2. Hal tersebut sejalan dengan pendapat Sari, (2014:1) yang menyatakan bahwa kemampuan siswa dalam menyelesaikan soalsoal yang berkaitan dengan bangun ruang rendah. Berdasarkan permasalahan tersebut, maka ada beberapa rumusan masalah yang akan disajikan dalam penelitian ini, yakni: (1) bagaimana learning obstacle yang terkait dengan kemampuan pemahaman matematis siswa pada materi balok dan kubus?, (2) bagaimana desain didaktis bahan ajar berbasis pengembangan kemampuan pemahaman matematis siswa pada materi balok dan kubus?, (3) bagaimana implementasi desain didaktis bahan ajar berbasis pengembangan kemampuan pemahaman matematis siswa pada materi balok dan kubus? Adapun tujuan penelitian ini adalah (1) mengetahui dan menjelaskan learning obstacle yang terkait dengan kemampuan pemahaman matematis siswa pada materi balok dan kubus, (2) mengetahui dan menjelaskan desain didaktis bahan ajar berbasis pengembangan kemampuan pemahaman matematis siswa pada materi balok dan kubus, (3) mendeskripsikan implementasi desain didaktis bahan ajar berbasis pengembangan kemampuan pemahaman matematis siswa pada materi balok dan kubus.

\section{METODE}

Penelitian ini menggunakan penelitian desain didaktis. Fokus penelitian adalah mengkaji kesulitan belajar siswa dalam konsep balok dan kubus sehingga menjadi suatu dasar untuk merancang suatu desain didaktis dan bahan ajar agar dapat mengantisipasi kesulitan belajar tersebut serta dapat mengembangkan kemampuan pemahaman matematis siswa. Subyek penelitian siswa kelas IV SD.

Adapun prosedur penelitian yang dilakukan adalah prospective analysis, experiment dan retrospective analysis. Teknik pengumpulan data yang digunakan dalam penelitian ini adalah tes 
dengan instrumen berupa soal, observasi partisipatif, wawancara, angket, dan dokumentasi. Peneliti menyusun instrumen tambahan yang berupa tes tertulis berbentuk essay. Selain itu, peneliti juga menyusun hypothetical learning trajectory (HLT) beserta antisipasinya.

Teknik analisis data utama menggunakan teknik analisis data kualitatif. Data dianalisis dengan menngunakan analisis kualitatif. Analisis kualitatif dilakukan selama proses pengumpulan data, sampai dengan hasil pengumpulan data.

\section{HASIL DAN PEMBAHASAN}

Hasil penelitian yang akan disajikan diantaranya mencakup desain didaktis awal dan desain revisi. Desain didaktis ini disusun untuk meminimalisir learning obstacle yang telah terungkap. Desain pembelajaran ini merupakan salah satu tahapan agar tujuan pembelajaran dapat tercapai.

\section{Prospective Analysis Desain Awal}

Kegiatan pembelajaran pemahaman matematis pada materi balok dan kubus ini berawal dari kehidupan sehari-hari siswa tentang benda-benda yang berbentuk balok dan kubus, diantaranya buku, penghapus, rubik, dan lain-lain. Hal ini sejalan dengan pendapat Astuti, dkk (2013:6) yang menyatakan bahwa proses belajar matematika memerlukan keterlibatan peserta didik yang berangkat dari dunia nyata, semakin bertambah aktif anak dalam belajar matematika semakin ingat anak dengan konsep matematika yang dibelajarkan. Desain pembelajaran diawali dengan menunjukkan contoh-contoh bangun ruang seperti kotak pensil, bungkus pasta gigi, dan lain-lain. Kegiatan pembelajaran dilanjutkan dengan menganalisis unsur-unsur yang terdapat pada bangun ruang. Kegiatan ini, diawali dengan media yang sudah disediakan yaitu kotak pensil untuk menunjukkan unsur-unsur tersebut. Pada tahap selanjutnya peneliti menggambarkan contoh bangun ruang di papan tulis.

Kegiatan dilanjutkan dengan menghubungkan unsur-unsur yang terdapat pada bangun ruang dengan ciri-ciri balok dan kubus. Analisis terhadap ciri-ciri yang terdapat pada bangun ruang dilakukan melalui media yang tersedia. Pembelajaran dilanjutkan dengan melihat gambar yang telah tersedia di papan tulis. Siswa melihat bentuk bangun ruang kubus dalam bentuk gambar. Disini perlu ditekankan bahwa kubus itu sisinya berbentuk persegi dan bukan gambarnya yang persegi. Kemudian siswa dibagi menjadi tujuh kelompok dan mengerjakan LKS secara berkelompok.

Dalam kegiatan akhir, peneliti memberikan soal evaluasi yang harus dikerjakan secara mandiri oleh tiap siswa dengan tujuan melihat sejauh mana kemampuan tiap siswa dalam memahami materi bangun ruang balok dan kubus dipembelajaran desain awal ini.

\section{Implementasi Desain Didaktis Awal (Experiment)}

Dengan mengimplementasikan desain didaktis tersebut dapat diperoleh beberapa hal. Pertama, pengembangan pemahaman konsep bangun ruang. Pada bagian ini, proses pembelajaran diawali dengan menunjukkan contoh-contoh bangun ruang seperti kotak pensil, bungkus pasta gigi, dan lain-lain. Selanjutnya, peneliti menggali pengetahuan awal siswa mengenai pengertian bangun ruang. Kegiatan pembelajaran dilanjutkan dengan menganalisis unsur-unsur yang terdapat pada bangun ruang. Kegiatan ini, diawali dengan media yang sudah disediakan yaitu kotak pensil untuk menunjukkan unsur-unsur tersebut. Hal tersebut sesuai dengan teori Brunner yang pertama yaitu enaktif. Sejalan dengan pendapat Tanzimah, et al. (2013:113) menyatakan bahwa media/gambar perlu diperhatikan dalam pembelajaran matematika. Selain itu, siswa dituntut untuk memahami unsur-unsur bangun ruang selain pada bangun ruang sebenarnya juga pada gambar. Adanya tuntutan itu, maka pada tahap selanjutnya peneliti menggambarkan contoh bangun ruang di papan tulis. Dalam hal ini, siswa dituntun untuk menunjukkan dan memahami unsur-unsur bangun ruang pada gambar yang telah dibuat. Selanjutnya, salah seorang siswa diminta untuk maju kedepan dan menunjukkan unsur-unsur yang terdapat pada bangun ruang.

Kedua, Pengembangan pemahaman konsep balok dan kubus. Kegiatan pembelajaran pada bagian ini, diawali dengan menunjukkan kembali bangun ruang yang telah disediakan. Siswa menyebutkan nama dari bangun ruang yang dipegang guru, kemudian secara aktif menyebutkan nama dari bangun ruang tersebut. Berdasarkan antispasi yang telah dibuat, masih ada siswa yang belum mengetahui balok maupun kubus. Namun, hal tersebut dapat teratasi. Selanjutnya, menghubungkan unsur-unsur 
yang terdapat pada bangun ruang dengan ciri-ciri balok dan kubus. Analisis terhadap ciri-ciri yang terdapat pada bangun ruang dilakukan melalui media yang tersedia. Siswa dalam kegiatan ini memperhatikan dengan seksama.

Ketiga, Pengembangan pemahaman konsep balok dan kubus melalui gambar. Pada bagian ini, pembelajaran dilanjutkan dengan melihat gambar yang telah tersedia di papan tulis. Siswa melihat bentuk bangun ruang kubus dalam bentuk gambar. Disini perlu ditekankan bahwa kubus itu sisinya berbentuk persegi dan bukan gambarnya yang persegi. Hal tersebut berdasarkan antisipasi masih adanya siswa yang memahami bahwa kubus itu persegi. Kegiatan ini menemukan siswa mengenal bentuk persegi dengan sebutan persegi empat. Peneliti mencoba meluruskan bahwa sisinya itu persegi bukan persegi empat. Selanjutnya, siswa dibentuk kedalam tujuh kelompok. Dalam pembentukannya terjadi kegaduhan, karena ada kesalahan ketika proses pembagiannya. Setelah itu, kegiatan pembelajaran dapat dikendalikan kembali. Setiap kelompok diberi LKS. Siswa saling bekerjasama dalam proses pengerjaannya.

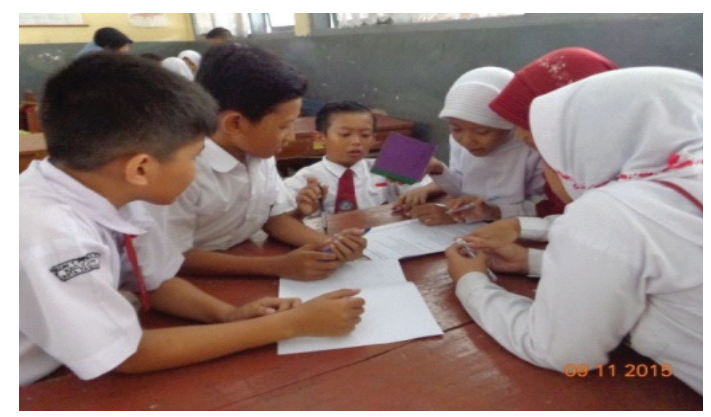

Gambar 2. Pengerjaan LKS secara berkelompok

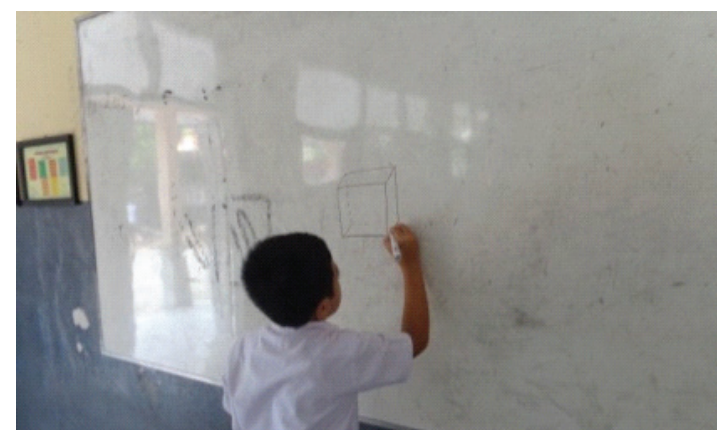

Gambar 3.Kegiatan siswa saat menggambar bangun ruang

Peneliti membimbing dan mengarahkan siswa pada saat pengerjaan LKS kepada setiap kelompok, dengan tujuan agar tetap kondusif. Setelah selesai, peneliti mengulas dan meluruskan jawaban yang diberikan siswa. Kemudian meminta siswa untuk menggambarkan balok dan kubus di papan tulis. Sedangkan, siswa lainnya diminta untuk memperhatikan bagaimana cara menggambar bangun ruang.

Desain ini perlu dipertahankan, karena dapat mengetahui sejauh mana pemahaman siswa tentang materi balok dan kubus. Selain itu, pembelajaran ini sesuai dengan tahapan belajar matematika menurut Brunner yaitu tahap ikonik yakni pembelajaran dengan memakai gambar. Akan tetapi, desain didaktis ini perlu dilakukan perbaikan supaya siswa tidak mengalami kesulitan dalam memahami soal.

\section{Restrospective Analysis Desain Awal}

Desain didaktis awal yang diimplementasikan harus diperbaiki sehingga disusunlah desain didaktis revisi. Beberapa revisi yang dilakukan yakni terkait dengan konteks soal, prediksi respon, bentuk penyajian dan waktu.

\section{Desain Didaktis Revisi}

Berdasarkan hasi revisi dari desain awal, desain ini lebih menarik minat siswa untuk mengikuti pembelajaran sekaligus mempermudah siswa dalan memahami materi mengenai konsep balok dan kubus. Selain itu, desain ini dilengkapi dengan kegiatan berupa kuis, agar materi yang disampaikan lebih bermakna. Kegiatan ini dapat memancing ketertarikan siswa pada pembelajaran matematika.

Berdasarkan hasil analisis, dapat digarisbawahi bahwa melalui desain didaktis, proses belajar siswa menjadi meningkat. Demikian juga, tingkat pemahaman siswa terhadap materi balok dan kubus juga menjadi meningkat. Hasil penelitian ini sesuai dengan hasil penelitian Sulistiawati, dkk (2015) yang menunjukkan desain didaktis yang dikembangkan dapat memperkecil gap yang dihadapi siswa. Kemampuan penalaran matematis siswa meningkat terlihat dari berkurangnya kesulitan-kesulitan yang di alami siswa dalam menyelesaikan soal penalaran matematis pada materi luas dan volume limas desain didaktis di kembangkan. Kebanyakan siswa memberikan tanggapan yang positif terhadap desain didaktis yang dikembangkan.

Hasil penelitian ini juga sesuai dengan hasil penelitian Aprianti, dkk (2016) yang menunjukkan hasil desain awal dan desain revisi yang sudah dimplementasikan menunjukkan bahwa adanya 
pengembangan kemampuan siswa setelah menggunakan bahan ajar pada desain didaktis yang disusun peneliti. Hasil penelitian ini juga sejalan dengan hasil penelitian Dl et al. (2014) yang menunjukkan bahwa bahan ajar (desain didaktis) pada materi sifatsifat bangun datar yang telah didesain dan direvisi mampu mengurangi miskonsepsi yang terjadi pada siswa.

\section{SIMPULAN DAN SARAN}

\section{Simpulan}

Dalam penelitian ini ditemukan tiga tipe learning obstacle yang dimiliki oleh siswa, yakni: (1) Tipe 1: Learning obstacle terkait pemahaman konsep bangun ruang; (2) Tipe 2: Learning obstacle terkait pemahaman konsep balok dan kubus; dan (3) Tipe 3: Learning obstacle terkait menggambar balok dan kubus. Berdasarkan hal tersebut, desain didaktis disusun untuk mengatasi learning obstacle yang ditemukan. Adapun, hasil penelitian menunjukkan bahwa desain didaktis dapat digunakan sebagai alternatif bahan ajar dan diimplementasikan dalam kegiatan pembelajaran.

\section{Saran}

Desain didaktis kemampuan pemahaman matematis siswa pada materi balok dan kubus yang dibuat ini, diharapkan pembelajaran dapat memberikan makna terhadap pembelajaran balok dan kubus itu sendiri yang berawal dari kehidupan sehari-hari dan memperhatikan karakteristik learning obstacle siswa yang muncul, kemudian membuat pembelajaran yang bermakna untuk siswa dengan menggunakan media pembelajaran yang langsung mengajak siswa untuk berperan aktif. Desain didaktis bahan ajar koneksi matematika ini dapat diterapkan oleh para guru untuk meminimalisir learning obstacle yang muncul dan menambah pemahaman siswa terkait materi balok dan kubus.

\section{DAFTAR RUJUKAN}

Aprianti, D.A., Karlimah, K., \& Hidayat, S. 2016. Desain Didaktis Pengelompokan Bangun Datar untuk Mengembangkan Komunikasi Matematis Siswa Kelas II Sekolah Dasar. Pedadidaktika, Jurnal Ilmiah Mahasiswa Pendidikan Guru Sekolah Dasar, 3 (1): 150-158.
Ariyanto, L. 2015. Pengembangan Perangkat Pembelajran Matematika Model Berjangkar (Anchored Instruction) Materi Luas Kubus dan Balok Kelas VIII. Pendidikan Matematika $1-13$.

Astuti, I. A., Marhaeni, A.A.I.N. \& Sariyasa. 2013. Pengaruh Pendekatan Matematika Realistik terhadap Prestasi Belajar Matematika ditinjau dari Kemampuan Numerik. Jurnal Penelitian Pascasarjana Undhiksa, 3(1):1-10.

Brousseau, G. 1997. Theory of Didactical Situation in Mathematics. Dordrecht: Kluwer Academic Publishers.

Dl, I., H, A., Ph, S., \& AML, D. 2014. Pengembangan bahan Ajar Berbasis Miskokonsepsi Siswa tentang Sifat-sifat Bangun Datar di Sekolah Dasar. Saung Guru, Sarana Aktivitas dan Unggulan Guru, 5 (2).

Hadi, S. 2005. Pendidikan Matematika Realistik dan Implementasinya. Banjarmasin: Tulip.

Happisari, R. 2013. Pembelajaran dengan Metode IMPROVE untuk Meningkatkan Pemahaman Konsep Matematika Siswa Kelas VII A SMP Negeri 1 Karangmoncol. (Tesis). Universitas Muhammadiyah Purwokerto, Purwokerto.

Huda, N \& Kencan, A.G. 2013. Analisis Kesulitan Siswa Berdasarkan Kemampuan Pemahaman dalam Menyelesaikan Soal Cerita pada Materi Kubus dan Balok di Kelas VIII SMP Negeri Muaro Jambi. Semirata. 595-606.

Kesumawati, N. 2008. Pemahaman konsep Matematik dalam Pembelajaran Matematika. Seminar Nasional Matematika dan Pendidikan Matematika. FKIP Program Studi Pendidikan Matematika Universitas PGRI Palembang. tidak diterbitkan.

NCTM. 2000. Principles and Standars for School Mathematics. United States of America: The National Council of Teachers of Mathematics, Inc.

Ningsih, R.E.R. 2010. Penerapan Model Pembelajaran Creative Problem Solving Dengan Media Autograph Untuk Meningkatkan Pemahaman Matematika Siswa SMA. Universitas Negeri Medan, Medan.

Nur'aeni. 2010. Pengembangan Kemampuan Pemahaman dan Komunikasi Matematis Siswa SD melalui Pembelajaran Geometri berbasis Teori Van Hiele. Disetasi tidak diterbitkan. Bandung: UPI. 
Purwatiningsih, S. 2013. Penerapan Metode Penemuan Terbimbing untuk Meningkatkan Hasil Belajar Siswa pada Materi Luas Permukaan Volume Balok. Jurnal Elektronik Pendidikan Matematika Tadulako. 1(1), 53-63

Sari, I. P. 2014. Penerapan Pendekatan Kontekstual untuk Meningkatkan Kemampuan Siswa dalam Memahami Sifat-sifat Bangun Mata Pelajaran Matematika. Jurnal Didaktika Dwija Indria, 2 (6), 1-6.

Sulistiawati, Suryadi, D. \& Fatimah, S. 2015. Desain Didaktis Penalaran Matematis untuk Mengatasi Kesulitan Belajar Siswa SMP pada Luas dan Volume Limas. Jurnal Kreano Matematika Kreatif dan Inovatif, 6 (2), 135-146.
Suryadi, D. 2013. Didactical Design Research (DDR) dalam Pengembangan Pembelajaran Matematika. Prosiding Seminar Nasional Matematika dan Pendidikan Matematika (hlm. 3-12). Cimahi: STKIP Siliwangi.

Suwangsih, E., \& Tiurlina. 2010. Model Pembelajaran Matematika. Bandung: UPI Press.

Tanzimah, Somakim, \& Santoso, B. 2013. Desain Pembelajaran Operasi Penjumlahan dan Pengurangan Bilangan Bulat Menggunakan Media Permainan Kakisambe di Kelas IV Sekolah Dasar. Jurnal Sekolah Dasar, 22(2), 112-121. 